\title{
第35回日本老年医学会総会 一般演題（III )
}

\author{
座長：上田 一雄, 松本 昌泰, 赫彰郎, 山口 武典 \\ 斉藤 康, 内藤 周幸, 長谷川元治
}

\section{5. 無症候性脳梗塞病変における加齢と脳萎縮, お} よび血液レオロジー因子の变化に関する検討

香川医大第二内科

$$
\begin{aligned}
& \text { 高橋 務, 津田 能康 } \\
& \text { 佐藤 清人, 松尾 裕英 }
\end{aligned}
$$

目的：健常と思われる例で頭部 MRI 上にWhite Matter Lesions (WML) や Periventricular Hyperintensity（PVH）などの silent lesionsを認めること がある。そこで我々は無症候性脳梗塞病変における加 齢の影響と脳萎縮の進行程度, 血液レオロジー因子の 変化を検討することにより, 無症候性脳梗塞病変が有 する意義を検討した。

方法：対象は脳血管障害の既往がなく，明らかな局 所神経症状を示さない37例 (平均64歳)である。1.5T MRI (Gyroscan S15，Philips）を用いて，OM lineに 平行に $8 \sim 10 \mathrm{~mm}$ 間隔でスライスを得, スライス毎に脳 実質, 脳室, くも膜下腔の面積を測定し, 積算して体 積を算出した。脳萎縮パラメーターとして, 脳実質/頭 蓋容積 $(\mathrm{P} / \mathrm{S})$ 比, 脳実質/[脳室 $+<も$ 膜下腔 容積 $(\mathrm{P} /[\mathrm{V}+\mathrm{S}])$ 指数を用いた. WMLは $\mathrm{T} 2$ 強調像で high を, T1強調像で low を呈する径 $5 \mathrm{~mm}$ 以上の病变とし, PVH は Gerard ら (1986)の基準に従い 5 段階に分類, PVH を認めないものを grade 0 とした。血液レオロ

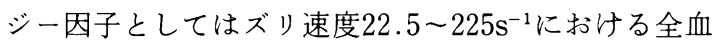
粘度, Ht 45\%時の標準化全血粘度と血漿粘度, 血漿 フィブリノーゲン濃度, フィブリノーゲン/アルブミン (F/A) 比, Yield Shear Stress (YSS) index を測定, 算出した。

結果及び考案：年齢と脳萎縮パラメーターである $\mathrm{P} / \mathrm{S}$ 比, $\mathrm{P}[\mathrm{V}+\mathrm{S}]$ 指数との間には有意な負の相関を 認め（各々 $\mathrm{p}<0.01 ）$ 加齢に従い脳萎縮の進行を認め た. WML 数は加齢に伴い有意の増加を示し（p< 0.05), WML 数の増加に伴って脳萎縮パラメーターで ある $\mathrm{P} / \mathrm{S}$ 比, $\mathrm{P} /[\mathrm{V}+\mathrm{S}]$ 指数は低値を示した. $\mathrm{PVH}$ の程度と加龄, 脳萎縮パラメーターとの間には有意な 相関を認めなかったが, PVHの程度が進行する程 WML 数は増加した。血液レオロジー因子に関しては, WML 数が $0 \sim 3$ 個の群と 4 個以上の群の 2 群に分け
た場合, WMLの多い群では少ない群に比べて血漿 フィブリノーゲン濃度, F/A 比, YSS index が有意の 高値を呈し(各々 $\mathrm{p}<0.05$ ), 一方, PVH が $0 \sim 2$ 度の 群と $3 \sim 5$ 度の群の 2 群に分けた場合には $3 \sim 5$ 度の 群は $0 \sim 2$ 度の群に比べて血漿フィブリノーゲン濃 度, F/A 比が有意の高值 (各々 $\mathrm{p}<0.05$ )を示し, 無症 候性病変の進行による血液レオロジー因子の変化が考 えられた。

\section{6. 脳塞栓症と脳萎縮 (Digitizer を用いて)}

公立陶生病院神経内科自島 章弘

名古屋総合リハビリテーションセンター神経 内科

松原 充隆

目的：老年者脳塞栓症患者で CT 画像を発症時より 経時的に観察したところ, 脳室の払大を伴ら大脳萎縮 を認め,これを客観的に評価する目的でパーソナルコ ンピュータ-Digitizerを用いて検討した。 また可能な 症例で ${ }^{123} I-I M P$ SPECT で発症時より経時的に脳血流 測定を行い脳萎縮との関連について考察した。

方法 : 発症様式, 心房細動の合併, 脳血管撮影所見 より脳塞栓症と診断した症例で発症後 6 力月以上にわ たり経過を追跡し得た 30 (平均年齢69 08.2 歳)を対照 とした。CTを用いて OM-Line に平行のスライス面で $1 \mathrm{~cm}$ 幅で撮影を行い, この画像をパーソナルコン ピュータに集積した後 Digitizerを用いて独自の index を算出し脳室拡大と脳萎縮について評価した。 脳血流測定は発症後 1 週間以内と 3 力月後に施行し た。

結果：発症時に比して経過観察時には有意な脳室拡 大がみられ, 脳萎縮は軽度ながらみとめられた。 spect によりこの現象を検討すると脳血流は急性期より患側 で著明な低下をみ, 慢性期においても殆ど血液の回復 はみられなかった。

老年医学的意義：老年者慢性期脳血管障害患者では 健常老年者に比してCT などの検査で脳萎縮がより明 らかにみとめられ，またそれが剖検で確認されるが， 脳塞栓患者では短期間のらちに脳室拡大, 脳萎縮が画 像上認められこれは慢性的な脳血流低下と関連がある 
ものと考党られる。

77. 脳萎縮の経年变化に関する検討 (第 4 報) 一高 血圧症の重症度との関連一

奈良県立医大第一内科

$\begin{array}{lrrrr}\text { 山野 } & \text { 繁, 澤井 } & \text { 冬樹, 森本 } & \text { 真弓 } \\ \text { 小松 } & \text { 正佳, 森岡 } & \text { 泰子, 澤井 } & \text { 伸之 } \\ \text { 沢田 } & \text { 泉, 籠島 } & \text { 忠, 土肥 } & \text { 和紘 }\end{array}$

目的：脳萎縮の経年変化に対する高血圧症の影響に ついて検討した。

方法：対象は, 当科に通院中の患者で, 頭部 CT 画 像に梗塞, 出血および腫瘍を示唆する所見のない患者 126例（男性57例，女性69例，平均年㛔62歳）である。 高血圧症の病期分類は, 眼底が Scheie 分類の $\mathrm{H}_{1}$ であ る以外に臟器障害を認めない時期を I 期, 心電図・胸 部 X 線像で左室肥大を示す時期をたは Scheie 分類の 眼底変化が $\mathrm{H}_{2}$ である時期を II 期とした。対象を, 高血 圧症を合併しない C 群 (59例, 平均年齢61歳) と高血 圧症を合併寸る $\mathrm{HT}$ 群 (67例, 平均年齢63歳) に, さ らに HT 群を高血圧症の病期が I 期の HT-I 群と II 期の HT-II 群に分けた。 また, HT 群を心・眼合併症 から, 左室肥大所見の有無によって LVH $(+)$ 群と $\mathrm{LVH}\left(\right.$ (一)群に, 眼底所見から $\mathrm{H}_{0}$ または $\mathrm{H}_{1}$ の群 $\left(\mathrm{H}_{0-1}\right.$ 群) と $\mathrm{H}_{2}$ の群 $\left(\mathrm{H}_{2}\right.$ 群) に分けた。脳萎縮は, 頭部 $\mathrm{CT}$ における尾状核頭部間距離を頭蓋内板間最大距離で除 した值 (Caudate head index; CHI) で評価した。頭 部 CT は $5 \sim 11$ 年（平均 6.9 年）の間隔で 2 回実施し, $\mathrm{CHI}$ の年平均増加量 $(\Delta \mathrm{CHI})$ を算出した。

結果：HT群の $\Delta \mathrm{CHI}$ は, $0.36 \pm 0.20$ であり, C 群 の0.26 0.15に比して有意に高值を示した。 HT-II 群

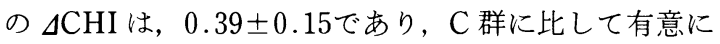
高かったが，HT-I群と差を示さなかった，LVH(+)

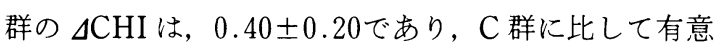
に高かったが, LVH (一) 群と差を示さなかった。一 方, $\mathrm{H}_{2}$ 群の $\Lambda \mathrm{CHI}$ は, $0.44 \pm 0.17$ であり, $\mathrm{H}_{0-1}$ 群の $0.31 \pm 0.21 お$ よびC 群に比してそれぞれ有意に高值 を示した。

結論：高血圧による臟器障害の徵候を認める高血圧 症患者は, 脳萎縮の経年変化が大であった。 また, 眼 底所見は, 左室肥大所見に比して高血圧症患者の脳萎 縮の経年変化を反映すると考兄られた。

78. 血糖上昇の脳・末梢循環に及ぼす脳幹障害の影 響一とくに橋縫線核および橋網様体の関与について一
埼玉医大神経内科

小野田敦浩，島津 邦男，大久保 毅 丸木 雄一, 金 浩澤, 浅野 賀雄 中里 良彦, 澤田 雅彦, 古屋 大典

濱口 勝彦

目的：加齢と共に椎骨・脳底動脈系の循環障害を示 唆する症候にしばしば遭遇する。近年, 脳幹諸核のう ち糖代謝異常を介して, 脳循環代謝に関与する核の存 在が示唆されている.

本基礎研究では脳ブドウ代謝に対する関与が報告さ れている縫線核, おょび脳幹網様体が血糖上昇時の 脳・末梢循環に与兄る影響を検討した。

対象・方法：サル（macaca fuscata）12頭を用い, $\alpha$ クロラロース, ウレタン腹腔内麻酔後, 臭化パンク ロニュウムにて非動化し調節呼吸とした。橋縫線核 (RN) および橋網様体 $(\mathrm{RF})$ に電極（先端径 $30 \mu \mathrm{m}$ ) を刺入し, 凝固破壊 ( $1 \mathrm{~mA}, 1 \mathrm{~min}$ ) 群（各々 $\mathrm{RN}$ 群 5 頭， $\mathrm{RF}$ 群 3 頭）と刺入のみの対照群（C 群 4 頭）を作 製した。

零安定下電磁流量計プローベを内頸動脈, 椎骨動脈, 外頸動脈および大腿動脈に直接装着して血流を測定 し，血圧・脈拍と共に連続記録した。

結果：I]脳・末梢循環：1）椎骨動脈系一 $\mathrm{RN}$ 破壊 群は RF 破壊群, C 群に比較し, 高血糖状態作成 $1 \sim 9$ 分後に血流増加率が有意に小であった $(\mathrm{p}<0.05) .2)$ 内頸および大腿動脈系一高血糖負荷中に打いて， RN 群, RF 群, C 群いずれの 2 群間にも有意な差を認めな かった.3）外頸動脈系一 RN 群, $\mathrm{RF}$ 群は C 群に比し, 高血糖負荷直後, 一過性であったが有意に血流増加率 が小であった $(\mathrm{p}<0.05)$. II]血圧：高血糖状態作成直 後, 各群とも一過性に低下したが, その低下率は $\mathrm{RF}$ 群 で他の 2 群に比し有意に小であった $(\mathrm{p}<0.05)$. III] 脈拍：高血糖負荷により明らかな变化を示さず， 3 群 間にも差を認めなかった。

結語：以上の成績は，橋縫線核が血糖上昇時の脳幹 血流変動に関与することを示㖫する。

\section{Binswanger 型白質脳症一典型例と非典型例の} 比較一

都老人医療センター神経内科

山之内 博, 名倉 博史, 板東 充秋

喜多也寸志, 村田 美穂, 三谷 和子

榎本 武郎, 吉野 正俊

目的：脳血管性痴呆の代表的なものの一つである 
Binswanger 型白質脳症 (progressive subcortical vascular encephalopathy, PSVE と省略) には，広範な 大脳白質障害を示す典型的な例から白質病変が比較的 軽いもの, あるいは病变の分布が片寄っているものな ぞ, 非典型例がある. PSVEの発症要因を追求する上 で, 典型的な例がどのような特徵を持っているかの検 索は重要である.

対象と方法：最近の老年者の剖検例の中から典型的 な PSVE病変を示した 47 例と非典型的な所見を示し た46例を無作為に選択し，それぞれの臨床的，ならび に病理学的な特徵を検討した。非典型例としたのは, 白質病変の軽い例, 病変が前方あるいは後方に片寄っ ているもの, 正常圧水頭症を合併したもの, などであ る. 対象の性別, 年齢は典型例では男26例 (平均年齢 78.7 歳), 女21例 (同, 82.0 歳), 非典型例では男25例 (同, 81.0歳), 女21例 (同, 85.2歳).

結果：1）高血圧（既往も含む）は典型例の $75 \%$ に, 非典型例の $61 \%$ に認められた。CVDの既往歴は典型 例, 非典型例で差がなかった。無言・無動状態は典型 例の $45 \%$, 非典型例の $15 \%$ に認められた。2）太い脳動 脈の動脈硬化の程度は両群間で差がなかったが, 白質 内の小・細動脈の硝子様変化は典型例で高度のものが 多い傾向が見られた。高血圧性脳出血の併存は典型例 の群では大出血 2 , 中小の出血17例, 非典型例ではそ れぞれ $0 ， 9$ 例であり，典型例に多かった。

考察とまとめ：Binswanger 型白質脳症の典型的な 例に限ってみると，ょり高血圧ならびに高血圧性血管 病変との関係が強いように思われる。逆に云えば, 非 典型例の中には高血圧以外の因子の関与しているもの がかなり含まれている可能性がある。

\section{0. 血栓型脳梗塞の検討：主として血液へマトク} リット值の観点から

$$
\text { 都老人医療センター・神経内科 }
$$

榎本 武郎, 板東 充秋

名倉 博史, 山之内 博

目的：血栓型脳梗塞急性期の血液へマトクリット (Hct)值と, CT・脳血管撮影所見, 高血圧症, 糖尿病, 飲酒・契煙習慣との関係を調へ，高齢者の特徵につい て検討する。

対象：発症 1 週間以内の血栓型脳梗塞例で, 脳血管 撮影を施行された連続184例（男98例，女86例）を対象 とした。平均年齢は73歳．DICを伴う症例は含まれな い.
方法：脳血管撮影所見は閉塞および狭窄度 $50 \%$ 以上 (高度動脈硬化群), 狭窄度25～50\%未満，25\%未満に 分類した。梗塞巣の確定は X 線 CT・MR 画像に拠り, 深部・皮質・脳幹梗塞群に大別した。高血圧症・糖尿 病は罹病年数を評価し, 乫煙量の評価にはS Smoking Index $(\mathrm{SI})=$ 乫煙本数 $/$ 日 $\times$ 年数を用いた。飲酒習慣は あり・なしの 2 群に分類した。

結果：(1) 入院時 Hct 值 $40 \%$ 以上を示したのは全 例の $58.7 \%$ であった。男性群の約 8 割を占めていた。

(2) Hct 值 $45 \%$ 以上の高值例は全例の約 $20 \%$ で比較的 低い年齢層 (70歳未満) が多かった。（3）入院時 Hct 值 $45 \%$ 以上の男性群では平均值 $48.8 \%$ から退院時の平 均値 $41.5 \%$ へ有意の低下がみられた。（4）高血圧症と Hct 值との間に相関はみられなかったが, 糖尿病群 56 例のうち約 6 割が Hct 值 $40 \%$ 以上であった。（5）契煙 群は非妿煙群に比し Hct 值が高く $(\mathrm{p}<0.005)$, (6) 飲 酒群 (男) では非领酒群に比し Hct 值が高い傾向がみ られた $(\mathrm{p}<0.05)$. (7) 脳血管閉塞を53例に認め, $73.6 \%$ が70歳以上の症例であった。（8）高度動脈硬化 群では内頸動脈系で Hct 值 $40 \%$ 以上例が多く, 椎骨動 脈系で $40 \%$ 未満例が多かった。（9）梗塞巣について Hct 值 $45 \%$ 未満群と $45 \%$ 以上群とに分けて脳血管撮影 所見との関係を検討したが，明らかな相関は見いだせ なかった。

\section{1. 高へマトクリット血症を有する脳虚血発作例の}

\section{瀉血，補液による再発防止療法に関する研究} 金沢医大老年病科

関本博, 林 光義, 松本 幹生
李 寧章, 高崎 幹裕, 奥谷 幸彦
宗平 純一, 林 淳史, 今村 早生

約30年前より, 演者らは老年者の早朝覚醒時の高へ マトクリット血症が脳卒中に結び付くことを見いだ し, 摂水の増加を勧め, 脳卒中の発症予防を目的とし て生活指導を行ってきた。飲水量の増加のみではこの 効果にも限界があり, 瀉血を併用し，1回の瀉血量は $200 \sim 400 \mathrm{~m} l$ とし，同時に生食水に $50 \%$ グルコースを 添加したものを点滴静注する療法を行った。対象は60 歳以上の男子と女子 11 例について $1 \sim 12$ 年間追跡治療 した. CT, MR-CT などで多発性脳梗塞を認める例に 再発予防について検討を行った，全ての治療例で補液 直後の $\mathrm{Ht}$ 值は通常 $3740 \%$ 示した。補液中は 1 l $\mathrm{minO}_{2}$ 吸入を持続した. その後 4 週間に一度, $\mathrm{Ht}$ 值を検 索し，40\%を越えた時は再び瀉血と補液を行っている 
が今迄のところ, 再発予防に有効な手段である成績が 得られている。

\section{2、脳血管障害患者の血小板に及ぼす喫煙の影響} 東京医大老年科

中野 正剛, 岡田 豊博, 新 弘一

岩本 俊彦, 高崎優

目的：契煙の血小板に及ぼす影響について，血中 $\beta$ トロンボグロブリン（以下 BTG）濃度を血小板活性化 の指標として，慢性期脳血管障害患者を含むボラン ティアで，その妿煙前後に BTG 濃度を検討した。

方法：対象は I 群。喫煙習慣の続いている脳血管障 害後遺症10例，II 群。脳血管障害の既往のない20例 （age-match した II -a 群10例，若年健常者の II-b 群10 例) で早朝喫煙前 (A) と随意の契煙（タバコ 1 本） 10 分後 (B) の 2 回採血し, 各々型通りの方法で BTG 濃 度を測定した。得られた（A)および（B)より $\mathrm{B} / \mathrm{A}$ 比 を变化率として血小板活性化の程度を検討した。

結果：1）契煙群は一例を除いて全て男性で,年齢は I 群57〜84歳，II-a 群51〜81歳であった。2） I 群の BTG-A は $57.0 \pm 28.6 \mathrm{ng} / \mathrm{m} l$ と高く，さらに契煙後の BTG-B は73.4 $237.9 \mathrm{ng} / \mathrm{m} l$ とさらに上昇した $(\mathrm{p}<$ $0.10)$. 3）各群の B/A 比は I 群 $1.34 \pm 0.39$, II-a 群

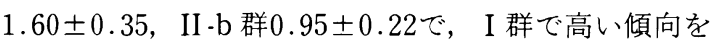
示し, II-b 群との間に有意差を認めた。 4）平均 B-A 值 は I 群（16.0土24.8）で有意に高かった。

老年医学的意義：哭煙が生体に与兄る影響のうち, 動脈硬化や血栓症の重要な発症要因として疫学的に知 られているが, 血小板放出因子からみた検討は少ない。 今回，脳血管障害慢性期にある喫煙常習者では，既に 血小板活性化がみられた所見は広範な血管病変の存在 を示し，さらに喫煙での増強は血管病変の進展する可 能性が示唆された。以上から契煙が脳卒中の危険因子 とされる一方，この評価法が喫煙者における血管病变 の規模を知る上で有用な方法であると考兄られた。

\section{3. 抗血小板剂投与前後の凝血学的検查項目の変動} について

公立井波総合病院内科

定梶 裕司，南真司 金沢大第三内科

朝倉 英策, 斉藤 正典, 魚谷 知佳

熊走 一郎, 森下英理子, 山崎 雅英

青島 敬二, 松田 保
目的：虚血性脳血管疾患の secondary prevention にアスピリンとチクロピジンが汎用されているが，こ の 2 凨投与前後において凝固線溶系のパラメーターの 変動については未だ詳細な検討は無く, 今回高齢者を 主にこの点について検討した。

対象及び方法：対象は，慢性期脳梗塞27例 (男17例, 女10例）と無症候性脳梗塞14例（男 8 例，女 6 例）の 合計 41 例 (平均年齢 $72.8 \pm 8.6$ 歳) である。抗血小板剂 としてアスピリン $(81 \mathrm{mg} /$ 日) 及びチクロピジン（200 $\mathrm{mg} /$ 日）を使用した。投薬期間は各々 $3 \sim 6$ 週間とし て，一方の薬剂を投与した後休薬期間を設けずに他剂 に変更した。採血は, 抗血小板剂投与前之各薬剂投与 $3 \sim 6$ 週後の合計 3 回行った. 測定項目は, 血算, 一 般凝血学的検査, プラスミノゲン・アクチベーター・ インヒビター-1 (PAI-1), プラスミン・ $\alpha_{2}$ アンチプラ スミン複合体 (PIC), 血小板凝集能 (ADP : 終濃度 8 $\mu \mathrm{mol} / l$ ) である.

結果：両薬剤投与後に最大血小板凝集率 $(\mathrm{ADP}$ 終濃 度 $8 \mu \mathrm{mol} / l$ ) は投与前に比較して有意に低下した。 た，凝集パターンで分類した検討でも，凝集能は低下 したと考えられた。投与前後の血小板凝集率の差と加 齢との間には，両薬剤ともに有意な関連はなかった。 アスピリンの ADP 凝集抑制作用は，性別に関係なく 認めた。一方, PAI-1を含むその他の項目には有意な変 動はみられなかった。

考察：少量のアスピリンでも十分な血小板凝集能低 下作用がみられ，また，チクロピジンでも欧米での 500 $\mathrm{mg} /$ 日といら高用量でなくとも本邦例では十分な血小 板凝集低下作用をもたらすと考光られた。充た，凝集 能の低下の程度は年齢とは無関係であり, 年齢で投与 量を増減する必要はないと思われた.ADP 凝集能でみ る限りアスピリンの凝集抑制作用は性別に関係なく, 抗血小板効果が期待される結果であった。

\section{4. 心房細動患者の脳血管障害及び全身塞栓症に関} する研究一再発と抗凝固療法について

佐久市立国保浅間総合病院内科 中島 一夫，一八瀬正彦，高田 進一

目的：1）心房細動 (Af) 患者の脳血管障害及び全身 塞栓症の内容，2）再発例の頻度及び発症時期，3）抗 凝固療法の有無と再発率を retrospective study にて 検討する。

対象：Af 619例を1983年 3 月から1993年 2 月迄の 10 年間観察し, 臨床上初発と考兄られる脳血管障害ない 
し全身塞栓症は135例にみられた。脳血管障害は126例 で, 塞栓症が78例 (男 43 , 女 $35,73.0 \pm 8.9$ 歳), 血检 症が31例 ( $22,9,74.9 \pm 7.5$ ), 梗塞が 12 例 ( 8,4 , $79.8 \pm 5.5)$ 及び出血が 5 例 $(1,4,79.4 \pm 3.3)$. 全 身塞栓症は87例で, 脳塞栓症が78例 (89.7\%), その他 の塞栓症が 9 例(腎 7 例, 四肢 2 例). 塞栓症例の Af の 型は慢性が73例 (84\%), 基礎心疾患別では lone が42例 (48\%), 高血圧性心臟病が24例, 弁膜症が13例, 虚血 性心疾患が 5 例であった。

成績：再発は31例（37回）に生じた（再発率23.0\%） が, 全身塞栓症（初回） $\rightarrow$ 全身塞栓症（再発）が24例 (26回) と高率. 抗凝固療法未施行19例の再発時期をみ ると, 1 力月以内 7 例 $(36.8 \%), 1$ 年以内が 13 例 (68.4\%). 抗凝固療法施行群24例 (平均年齢71.7歳, 平均観察期間 29.0 力月) と未施行群68例(73.0歳, 20.7 カ月）（ 5 例の重複あり。年齢, Af の型, 基礎心疾患に 有意差なし）で塞栓症再発率をみると，施行 Af 群で $5.2 \% /$ 年, 未施行群で $17.0 \% /$ 年 $(\mathrm{p}<0.05)$, 弁膜症を 除くと, 施行群 (19例, 平均観察期間 26.3 力月)で $2.4 \%$ / 年, 未施行群 $(59$ 例, 22.0 力月)で $15.7 \% /$ 年 $(\mathrm{p}<0.01)$ であった。

結語：心房細動患者の脳血管障害の $62 \%$, 全身塞栓 症の $90 \%$ は脳塞栓症で，その約半数は基礎心疾患を有 しない loneAf 例であった。再発は23\%に生じ, 初回全 身塞栓症から全身塞栓症再発のタイプ多く, 再発は 1 年以内に集中する傾向にあった。抗凝固療法にて全身 塞栓症の再発は有意に減少した。全身塞栓症を発症し た心房細動例では，比較的早期よりの積極的な抗凝固 療法が必要である。

\section{5. 脳卒中急性期の中性脂肪の上昇機序の検討.}

\section{IL-6の役割。}

$$
\text { 日本医大第二内科 }
$$

福生 吉裕, 赤石 治美, 小林 陽二 赫彰郎, 大村 直子, 村松忠 本田 治久

目的：脳梗塞急性期に扔いて, 中性脂肪は一過性に 第 $3 \sim 5$ 病日をピークとして上昇する。この現象は治 療薬剤であるグリセオールの干渉作用としてあまり注 目されていなかったが，私達は真の中性脂肪測定法を 用いることょりこの現象が存在することを明らかにし てきた。今回この中性脂肪の上昇機序を明らかにする ためにその分解酵素である Lipo protein lipase(LPL) とサイトカインを測定しその関連について検討したの
で報告する。

対象と方法：a）発症後24時間以内に入院した脳梗 塞18名, TIA 5 名, 脳出血 7 名である. 経時的に血清 脂質 (T-CHO, T-G，HDL) を空腹時採血した。中性 脂肪はデタミナー $\mathrm{TG}$ キットを用いた. $\mathrm{b})$ サイトカイ ン: IL-1 $\beta, \mathrm{TNF} \alpha, \mathrm{IL}-6$ ををンドイッチ法による ELISA 法で測定した。 c) Post heparin lipolytic activity（PHLA）の測定：脳梗塞患者12名について Heparin 10 単位 $/ \mathrm{kg}$ 静注後の血漿を ${ }^{14} \mathrm{C}$-Thioreinを 用いた Shotzの方法に準じて測定した。

結果：1）血清脂質の変動：総コレステロールは発 症日より次第に減少傾向を示した。しかし中性脂肪は 3〜 7 日にかけて発症日よりも有意に上昇を示した。

2) PHLA は第 $3 \sim 5$ 病日にかけて有意に減少を示し た. 3）サイトカインの経時的変動：TNF $\alpha$, IL- $1 \beta$ は 全経過を通じて何れも変動が見られなかった。しかし IL-6は発症時より $11.5 \pm 2.6 \mathrm{pg} / \mathrm{m} l$ と高值を示し, 第 3 病日, 第 7 病日と上昇傾向を示した. TIA ょりも脳 出血と脳梗塞は有意に上昇をしていた。 4) IL-6と中性 脂肪の相関：第 3 病日と 7 日目の值は $\mathrm{r}=0.53 \mathrm{p}<$ 0.001 と正の相関を示した。

結論：脳卒中後の脂質代謝異常にはサイトカイン (IL-6)が関与し，LPL の活性抑制をもたらし，中性脂 肪の上昇が生じたものと示唆された。

\section{6. 禁煙の脳血流に及ぼす影響}

$$
\text { 島根医大第三内科 }
$$

山下 一也, 小林 祥泰, 山口 修平 小出 博己, 今岡かおる, 卜蔵 浩和 須山 信夫, 土谷 治久, 梅枝 伸行 飯島 献一

目的：長期䒜煙は脳血流減少をきたすとされている が，禁煙が，脳血流にどのような影響を及ぼすかにつ いて追跡検討した報告は少ない，今回我々は, 禁煙前 後の脳血流を測定し，禁煙の脳血流に及ぼす影響につ いて検討した。

対象および方法：対象は我々が追跡調查している地 域健診対象の正常男性で，9年間経年变化を追跡し壳 た症例のらち, 追跡中禁煙した者(禁煙群) 6 名 (56〜82 歳, 66.8歳), および䒜煙歴がない者 (非喫煙群) 8 名 （62～84歳， 67.0歳）とした。局所脳血流 (rCBF) 測 定は $133 \mathrm{Xe}$ 吸入法により測定し，また，1秒率，\%肺活 量, 血圧, へマトクリット, 総コレステロール, HDL コレステロール, 心電図を初年度(禁煙前), 6 年後(禁 
煙直後), 9 年後（禁煙 3 年以上）の計 3 回測定した. さらに, 9 年目に MRI での白質障害の程度, 岡部式知 的評価尺度, Kohs 立方体組み合わせテストを比較検 討した。

すべての結果：rCBFは, 禁煙群では $60.3 \mathrm{~m} l / 100 \mathrm{~g} /$ $\min$ から 6 年後で 46.3 と有意の減少を示したが $(\mathrm{p}<$ $0.05), 9$ 年後には 62.3 と回復を示した。一方, 非契煙 群では $73.5 \mathrm{ml} / 100 \mathrm{~g} / \mathrm{min}$ から 70.5 ( 6 年後), 74.6 ( 9 年後）と変化はみられなかった。いずれの年度でも， 脳血流は禁煙群の方が, 初年度, 6 年度は, 非笫煙群 よりも有意に低值であったが，9年目には有意差は認 められなくなった。 また, 平均血圧は禁煙群では107.2 $\mathrm{mmHg}$ から, 95.7 ( 6 年後), 84.0 ( 9 年後) と有意に 低下し, 非契煙群は109mmHg, 100, 90 と低下したが, 有意な低下は認められなかった。その他呼吸機能, 脳 卒中の危険因子, MRI での白質障害の程度, 認知機能 に関しては，両群間に有意差を認めなかった。

結語：禁煙者の $\mathrm{rCBF}$ は非喫煙者よりは低值では あるものの, 禁煙により rCBF が回復する可能性が示 唆された。

\section{7. 脳血流と血圧のゆらぎの加齢的変化}

$$
\text { 聖マリアンナ医大第二内科 }
$$

$$
\begin{aligned}
& \text { 加茂 力, 岩崎みどり, 柴原 } \text { 公明 } \\
& \text { 北川 美恵, 斉藤加代子, 杉原 浩 } \\
& \text { 米山 公啓, 清水 亨 }
\end{aligned}
$$

目的：血圧・心拍・中大脳動脈血流速度は, ある規 則性をもって秒単位で変動している。これらの変動は 種々の周期変動の多重構造で構成されている。それぞ れの変動特性の加齢による变化を検討した。

対象：60歳以下の若年健常者（Y 群）10例（平均年 齢30歳）と61歳以上の老年健常者（O 群）10例（平均 年齢68歳) で検討した。

方法：血圧は Colin 社製 CBM-7000で, 脳血流のゆ らぎは $\mathrm{EME}$ 社製 TC2-64により中大脳動脈血流速度 を測定した。またDatex 社製 Oscarにて呼気 $\mathrm{CO}_{2}$ を 測定した。解析は最大エントロピー法 (MEM)により 平均血圧 $(\mathrm{MBP})$, 平均血流速度 $(\mathrm{MFV})$, 心電図 $\mathrm{RR}$ 間隔 $(\mathrm{RR})$ 及び呼吸時間 $(\mathrm{RF})$ の周期時間と, 最小二 乗法による最適当てはめ曲線から各周期成分の振幅と 位相を求めた。

結果：1）周期時間；MFV，MBP，RR ともに $0.01 \sim 0.1 \mathrm{~Hz}$ の低周波成分と $0.2 \sim 0.4 \mathrm{~Hz}$ の高周波成 分 $(\mathrm{HF})$ があり,さらに低周波成分は $0.1 \pm 0.01 \mathrm{~Hz}$

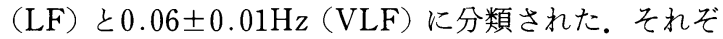
れの $\mathrm{HF}$ の周期時間は RF から求めた周期時間と一致 し, 呼吸性変動と考光られた。周期時間は $\mathrm{Y}$ 群と $\mathrm{O}$ 群 で差を認めなかった。2）振幅：LF とVLFでは MBP と RR は Y 群より O 群が有意に低值を示し, MFVで は差を認めなかった，HF では MBP, RR, MFVで差 を認めなかった。 3）位相：HFでは MFV, MBP, RR の位相は一致した. LF と VLFでは MFV と MBP 及 び MBP とRR の位相は, $3 \sim 10$ 秒のずれが存在し, O 群と Y 群で差を認めなかった。

考察：MBP, MFV, RR ともにVLF, LF, HF の重 畳により構成されることが示された。加龄によりそれ ぞれの周期時間は変化せず，MBP と RR においては VLF と LF の振幅が低下することが示された，MBP， $\mathrm{MFV}, \mathrm{RR}$ の LF と VLF の位相のずれが存在するこ とから，それぞれ異なる制御機構があり，また MFVの 振幅は加齢により変化しないことから，それぞれのゆ らぎに対する加齢の影響も解離することが推測され た.

\section{8. 脳血流量の経時的変化に及ぼす血圧の影響につ} いて

国療福岡東病院脳卒中センター

田川 皓一, 福原 正代

高野健太郎, 飯野 耕三

目的：脳血管障害慢性期の血圧管理にあたっては, 脳血管の自動調節能の障害に基づく血圧低下による脳 血流の減少に留意する必要がある。脳梗塞を対象とし て経時的に脳血流量を測定し, 血流量の変化と血圧の 変化との相関性を求め, 脳血管の自動調節能の障害へ の年齢や障害部位による影響について検討を加えた。

方法：対象は 1 回のシリーズに $1 \sim 2$ カ月の間隔で 3 回の脳血流測定を実施した慢性期脳梗塞患者の延べ 96 例で，65歳未満49例，65歳以上 47 例，皮質枝梗塞 74 例, 穿通枝梗塞 22 例であった。脳血流量は ${ }^{133} \mathrm{Xe}$ 吸入法 を用いて測定し, 半球平均脳血流量は各半球 9 個の検 出器から $F_{1}$ と ISI で求めた。第 1 回測定時と第 2 回測 定時, ならびに第 1 回測定時と第 3 回測定時における 脳血流量の変化率と測定時の平均動脈血圧の変化率の 相関性を求め, 全対象例, ならびに高年群と若年群, 皮質枝梗塞と穿通枝梗塞において, 脳血流量の経時的 変化に及ぼす血圧の影響について検討した。

結果：第 1 回測定時と第 2 回測定時, ならびに第 1 回測定時と第 3 回測定時に抢ける病巣側と非病巣側の 
$\mathrm{F}_{1}$ の変化率と測定時の平均動脈血圧の変化率の相関 係数を求めた。全対象例とともに，高年群と若年群， 皮質枝梗塞と穿通枝梗塞に分けて検討したが，いずれ の組合わせにおいても推計学的に有意な相関は認めら れなかった。 また, ISI も第 1 回測定時と第 2 回測定時 において, 同様の検討を実施しているが, 脳血流量の 変化と平均動脈血圧の変化率について有意の相関性は 得られなかった。

老年医学的意義：脳梗塞の血圧管理においては血圧 下降に伴う脳血流の減少が危惧されるところである. 脳血流量を複数回記録した脳梗塞例を対象に脳血流量 の変化率と血圧の変化率の相関を検討したところ, 有 意の相関はなく, とくに高年群で脳血管の自動調節能 が高率に障害されていることはなかった。

\section{9. 脳血管障害例における長期血圧変動の推移に関} する検討

昭和大神経内科

$\begin{array}{llrr}\text { 鈴木 } & \text { 義夫, 鈴木 } \quad \text { 衛, 市川 } & \text { 博雄 } \\ \text { 武井 直樹, 武内 } \quad \text { 透, 佐藤 } & \text { 温 } \\ \text { 福井 俊哉, 杉田幸二郎 } & & \end{array}$

目的：脳血管障害 (CVD) の血圧変動への経時的影 響を明らかにするために障害部位別に CVD 発症後の 血圧日内変動の推移を比較検討した.

対象：対象は発症時より血圧日内変動を追及し得た CVD 45例, すべて降圧薬非投与例であり, 内訳は脳梗 塞群30例（皮質枝梗塞 9 例, 単発性穿通枝梗塞 8 例, 多発性穿通枝梗塞13例）および脳出血群15例（被殼出 血 6 例, 視床出血 5 例, 橋出血 4 例）である。 また, 健常老人20例を対照とした。

方法：対象患者に対して携帯型血圧連続測定装置 (ABPM-630)を装着し, 発症時, 発症後 1 力月, 3 力 月, 6 力月, 1 年の平均の血圧・脈拍 ( $\mathrm{SBP}, \mathrm{DBP}, \mathrm{PR}$ ) および日中・夜間の血圧較差の推移について健常老人 に対比し検討した。

結果：1日の平均の血圧はいずれも発症時にピーク を示すが，その後低下傾向を認め，血圧下降の定常化 には皮質枝・単発性梗塞, 被殼出血では 1 力月, 視床, 橋出血では 3 力月, 多発性穿通枝梗塞では 6 力月を要 した．脈拍は変化は認められなかった。

日中・夜間血圧較差は発症時にはすべての CVD 例 で健常老人に比較して低下傾向にあるが, 健常老人と 同程度の血圧較差に回復するまでの期間は単発性穿通 枝梗塞では 1 力月, 皮質枝梗塞, 被款出血では 3 力月,
視床出血では 6 力月を要し, 多発性穿通枝梗塞, 橋出 血では 1 年以上を経ても血圧較差は低值であった。

結論：CVD 発症後の血圧変動異常は脳深部病変例 汪ど遷延する傾向が認められ, 回復過程には自律神経 障害の関与が示唆された。

\section{0. 慢性期虚血性脳血管障害患者における夜間血圧} 下降の臨床的意義

国立循環器病センター内科脳血管部門 中村 健正, 種田 二郎, 山口 武典

目的：慢性期虚血性脳血管障害患者に打ける，夜間 血王下降の影響を検討する。

対象及び方法：対象は, ADL 自立の慢性期虚血性脳 血管障害患者のうち, 携帯型連続血圧測定装置を用い て血王日内変動を把握し, その後の経過を観察し得た 76例. 内訳は降圧薬非服用者 (Med (-)) 33例（男25 例, 女 8 例, 平均64.7 59.2 歳), 降圧薬服用者 (Med (十) 43 例 (男36例, 女 7 例, 平均 $63.0 \pm 6.3$ 歳). 携 帯型血圧連続装置で得られた值をもとに, 平均血圧を 算出し, 日中 (6a.m.〜10p.m.) および夜間 (10a.m. 〜6 a.m.)の各時間帯の平均を計算した. そして, 日中の平 均血圧の平均 (MBP (Day)) と夜間の平均血圧の平均 $(\mathrm{MBP}(\mathrm{Night}))$ の差 $(\Delta \mathrm{MBP}=\mathrm{MBP}($ Day $)-\mathrm{MBP}$ (Night))が $10 \mathrm{mmHg}$ 以上のものを, 夜間血圧下降(D) 群, $10 \mathrm{mmHg}$ 未満のものを非下降 (N) 群とし, 二群 間で再発の有無, MRI 上の無症候性病変の推移を比較 した.

結果：(1) Med (-)33例の内訳は, D 群10例, N 群 23例で, Med (+) 43例の内訳は, D 群18例, N 群25 例であった。（2）平均追跡期間19.7士11.1力月の間に, Med (-) の10例 (D 群2, N 群8), Med (+)の 6 例 (D 群 $5, \mathrm{~N}$ 群 1 ) に再発がみられ, $\operatorname{Med}(+)$ において は夜間血圧下降群のほうが非下降群より再発が有意に 多かった $(\mathrm{p}<0.05)$.（3）Med $(+)$ において, 夜間 (起床時)再発の 4 例はいずれも D 群であった。(4) 非 再発例のらち, MRI 所見を経時的に観察し得たのは, $\operatorname{Med}(-)$ 18例 (D 群 5, N 群13), Med (十) 26例 (D 群 9, $\mathrm{N}$ 群17) で, このらち無症候性の梗塞の増加を 認めたものは, Med (一) 2 例(D 群 $0, \mathrm{~N}$ 群 2 ). Med (+) 5 例 (D 群 4, N 群 1) であった. 病変進行例 (再 発例 + MRI 上の無症候性脳梗塞の増加例) は, Med (一) では D 群, $\mathrm{N}$ 群間に差はなかった（D 群 2/7, $\mathrm{N}$ 群10/21）が, Med (+)においては, D 群のほうが 多かった（D 群 9/14, $\mathrm{N}$ 群 $2 / 18 ）(\mathrm{p}<0.01)$. 
老年医学的意義：慢性期虚血性脳血管障.害患者にお いて, 降圧薬投与下での夜間血圧の過度の下降は病変 の進行に関与する可能性が示唆された。

\section{1. 高齢者失語症の臨床的検討}

\section{成田記念病院神経内科川畑信也}

目的：高齢者（70歳以上）にみられる失語症につい てその病態を明らかにする。

方法：1990年 4 月から1993年 3 月までの 3 年間に脳 血管障害の治療のために入院または通院していた失語 症患者66名を対象として脳血管障害の病型之失語症の 類型について検討した。失語症の類型は標準失語症検 査（SLTA）ならびに Western Aphasia Battery 日本 語版に基ついて決定した。70歳以上の失語症患者（高 齢者群）は23名（男14名，女 9 名）で70歳から89歳の 間に分布していた。70歳未満 (非高齢者群) は43名 (男 30名，女13名）で34歳から69歳の間に分布していた。

結果：脳血管障害の病型は高齢者群で脳梗塞20名 $87.0 \%$ (脳血栓 12 名, 脳塞栓 6 名, 分類困難 2 名), 脳 出血 3 名 $13.0 \%$ であった。非高齢者群では脳梗塞28名 $65.1 \%$ (脳血栓 12 名, 脳塞栓 9 名, 分類困難 7 名), 脳 出血 9 名 $25.7 \%$ ，くも膜下出血 4 名 $11.4 \%$ であった. 失語症の類型は, 高齢者群では全失語 7 名 (30.4\%), ブローカ失語11名 (47.8\%), ウェルニッケ失語 4 名 (17.4\%)，超皮質性感覚失語 1 名（4.4\%）であった。 非高齢者群では全失語 5 名(11.6\%)，ブローカ失語 21 名 $(48.9 \%)$, ウェルニッケ失語 9 名 $(20.9 \%)$, 健忘 失語 6 名 (11.6\%)，伝導失語 1 名 $(2.3 \%)$ ，分類不能 2 名（4.7\%）であった。流暢性と加齢との検討では, 30 ４歳台で非流暢性失語の占める割合は $60 \%$ である が，50歳台 $61.5 \% ， 60$ 歳台 $66.7 \% ， 70$ 歳台 $69.2 \%$ 之加 齢に従いその頻度は漸増していき，80歳台では90\%に 及んでいた。

考察：高齢者にみられる失語症の基礎疾患としては 脳梗塞が大部分を占め, 脳出血やくも膜下出血による ものは少ない，高齢者群と非高齢者群間で Broca 失 語, Wernicke 失語の出現頻度に相違はないが, 全失語 は高齢者群に好発しやすい傾向がみられた。加齢に伴 い非流暢性失語が増加する傾向にあり，内言語の表出 面での障害のために日常会話で支障をきたす場合が多 いものと想定される.

92. 運動麻痺の回復が良好であった大脳皮質を含む 広範囲中大脳動脈領域梗塞症例の検討

\section{市立研波総合病院神経内科坂下 泰雄}

同 内科浅山 邦夫, 杉本 立甫

目的：大脳皮質を含む広範囲脳梗塞は重度の運動麻

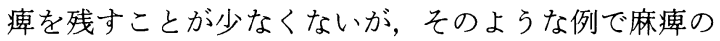
改善がきわめて良好な例がある。本報告では，運動麻 瘏が著明に改善した脳梗塞例を検討した。

対象と方法：症例は 2 年間に当院に入院した脳血管 障害例のうち, 運動麻疩が著明に改善した中大脳動脈 領域大脳皮質を含む広範囲脳梗塞の $67 \sim 80$ 歳の男性 6 例で，発症時の神経症候とその経過，血液検查，頭部 MRI，脳血流スキャンを検討した。

結果：発症は全例突然の運動麻㾝で，塞栓型の発症 様式であった，4 例は弛緩性左片麻痺で上肢の麻㾝が

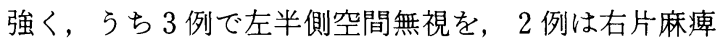
で，1例は失語症を伴っていた。意識レベルは 4 / 6 例 で3-3-9度方式の II であったが, 他の 2 例は清明であっ た. $4 / 6$ 例で心房細動が合併し, 他の 2 例で心室性あ るいは上室性期外収縮を認めた。心房細動合併例で心 房内血栓を証明できた例はなく，心臓弁膜症を合併し た例もなかった。高血圧が $3 / 6$ 例，糖尿病は $1 / 6$ 例 で合併しコレステロール值は全例で正常であった. $5 /$ 6 例が初回発作であった。発症後10日までに行った脳 血流スキャンで梗塞巣周辺の前頭葉部分での血流増加 を認めた，治療は脳浮腫対策と輸液で，血栓溶解剂は 使用しなかった。発症時の弛緩性運動麻㾇はいずれの 症例も発症後 $1 \sim 3$ 日から麻痷が回復しはじめ, 更に 10日前後で麻疩は著明に改善した。退院時までには日 常生活動作は自立し歩行も安定した。しかし, 左半球 損傷例では失語症を, 右半球損傷例では左半側空間無 視を残寸例があった。

まとめ：発症後数時間で急速に神経症状が改善する 脳梗塞を specutacular shrinking deficit と呼ぶこと があるが，本報告例の特徵は，稀ではあるが脳塞栓発 症後 3 日を経過してから麻痷が回復する例があったこ とで，発症時の予後判定に際して注意すべき一群があ ると思われる。

\section{3. アテローマ血栓性脳梗塞の臨床像の変遷}

国立循環器病センター内科脳血管部門 平野 照之, 種田 二郎 新井 鐘一, 山口 武典

目的：アテローマ血栓性脳梗塞 (ATH)の臨床像の 変遷について検討する。

方法：1978年 1 月から1991年12月期間の ATH 急性 
期初回入院連続 273 例（年齢 $66 \pm 11$ 歳，男 198 例，女 75 例）を対象とした。 入院時期により前期（～1985年） と後期（1986年以降）の 2 群に分け, 臨床症候, 病巣 部位， CT・血管撮影所見，危険因子，基礎疾患，転帰 などを比較した。

結果：年齢・性は前期群 $65 \pm 12$ 歳, 男 97 例, 女 50 例, 後期群 $67 \pm 10$ 歳, 男 101 例, 女 25 例であり, 後期群で男 性が増加した $(\mathrm{p}<0.01)$. 責任血管の病変部位は, 頭 蓋内が前期群 $75 \%$ から後期群 $56 \%$ に減少し（p< 0.01 ), 頭蓋外 (特に頝部内頝動脈の粥状硬化病変) が 45\%から59\%に増加した。合併疾患としては，前期群 と後期群でそれぞれ，高血圧が $76 \% ， 82 \%$ ，糖尿病が $43 \% ， 47 \%$ ，高脂血症が $25 \% ， 29 \%$ であ，契煙歴を 有するものが $62 \% ， 61 \%$, 閉塞性動脈硬化症を有する ものが $9 \%, 8 \%$ と有意な変化を認めなかったが, 虚 血性心疾患を有するものは前期群 $8 \%$ に比し後期群 $20 \%$ と有意に増加した $(\mathrm{p}<0.01)$.

老年医学的意義：これまで頭蓋外の血管病変は欧米 人に多く，日本人には少ないとされていた，今回の検 討では, 我が国でも最近では頭蓋外の血管病変は珍し くなくなっていることが明らかとなった．高年者に とって脳卒中の予防及び治療は言うまでもなく重要な 課題である。このような ATH の臨床像の変化は, そ の予防・治療において大きな意義を持つと考えられる.

\section{4. 超音波ドプラ法によるラクナ梗塞のスクリーニ ング診断（第 1 報）}

奈良県立医大第一内科

$\begin{array}{lrrr}\text { 澤井 } & \text { 伸之, 山野 } & \text { 繁, 森本 } & \text { 真弓 } \\ \text { 沢田 } & \text { 泉, 森岡 } & \text { 泰子, 籠島 忠 } \\ \text { 土肥 } & \text { 和紘 }\end{array}$

目的：超音波ドプラ法によるラクナ梗塞のスクリー ニング診断について検討した.

対象：対象は, 頭部 MRI が実施され, 脳出血, 脳腫 瘍および $15 \mathrm{~mm}$ を越える脳梗塞を除外した94例（男性 45例，女性49例）であり，年齢は32 94（平均61）歳 であった，対象を，65歳未満42例および65歳以上52例 の 2 群に分け, 各群を頭部 MRI 所見で中大脳動脈 (MCA) 領域に症候と相応するラクナを示した $\mathrm{S}$ 群, 症候を示さなかったがラクナを示した AS 群およびラ クナを示さなかった C 群に分類した.

方法：ラクナは，頭部 MRI の $\mathrm{T}_{1}$ 強調画像で低信号 かつ $\mathrm{T}_{2}$ 強調画像で高信号を示す直径 $5 \mathrm{~mm}$ 以上 $15 \mathrm{~mm}$ 未満の病変と定義した。次に, ラクナをスコア化し,
頭部 MRI で MCA 領域にラクナを示さなかったもの をラクナスコア0, 単発ないし 2 個のものをラクナス コア $1 ， 3$ 個以上のものをラクナスコア 2 として評価 した。総頸動脈血流動態の指標は, QFM-2000XA（林 電機製) による右総頸動脈血流量 $(\mathrm{BF})$, 頭蓋内血流動 態の指標は, Trans-scan (EME 社製)による右 MCA 血流速度 (MCA-BV) および pulsatility index (MCAPI）を用いた。

結果：65歳末満の若年者群あるいは65歳以上の老年 者群における BF, MCA-BV および若年者群における MCA-PIは，各群間で差を示さなかった。しかし，老 年者群における $\mathrm{AS}$ 群および $\mathrm{S}$ 群の PI 平均值は, そ れぞれ0.38,0.43であり，C群の0.29に比して有意に高 值 $(\mathrm{p}<0.05)$ を示した。 また，老年者群に打けるラク ナスコア 1 群および 2 群のPI平均值は, それぞれ $0.44,0.35$ であり, O 群の 0.29 に比して有意に高値 $(\mathrm{p}<0.05)$ を示した.

結論：老年者に抢ける中大脳動脈 PI 值の高値は, 中大脳動脈領域に抢けるラクナの存在を示唆する.

\section{5. 脳血栓初回発作時に随伴した MRI 变化：加齢 との関連}

東京医大老年科

岩本 俊彦, 小川 公啓, 宇野 雅宣

馬原 孝彦, 桜井 博文, 高崎 優

目的: 脳血栓初回発作時の MR 画像上り, 責任病巣 とこれに随伴する変化について，その意義と加齢との 関連を検討した。

方法: 脳血栓初回発作の94例を対象として, 発作後 3 力月以内に得られた MR 画像より，1）責任病巣の 型, 2) 脳室周囲信号度 (PVH) の変化, 3) 深部点状 病変 $(\mathrm{SL}), 4 ）$ ラクネを除く無症候性脳梗塞, 5) 脳室 拡大，6）皮質萎縮，7）痴呆との関係を検討した。コ ントロール（コ群）には非特異的神経症状を呈した40 例を用いた。

結果: 対象は男61例, 女33例で, 高血圧, 糖尿病は 各々 $65 \%, 24 \%$ に認めた。責任病巣の約半数は放線冠 一内包部であった。広範な PVH は脳血栓に多く,その $46 \%$ にられた。特に diffuse (4)は皮質枝梗塞で多く， 一方コ群では無変化(1)か $\mathrm{rim} / \mathrm{cap}$ (2)が85\%にみられ た。各 PVH の平均年齢は, (1)61.1歳, (2)71.0歳, (3) (patchy) 74.9 歳, (4)78.8歳と, 加龄とともに広範にな る傾向がみられた. SL はコ群との間に差はなく, 特徵 的なものはなかった。 ラクネを除く無症候性脳梗塞は 
血栓群の $20 \%$ と多かった。脳室拡大，皮質萎縮は脳血 栓症とは無関係で，脳室拡大有りの平均年齢は76.5歳 (無しは69.8歳), 皮質萎縮高度の年齢は77.4歳（軽度 は60.2歳) と加齢に関連し，これら二者は MRI 変化の うちで痴呆に強く影響（多变量解析数量化II類）して いた。

老年医学的意義：たと光脳血栓発作が初発でも，責 任病巣に随伴する種々の MRI 変化の意義を，無症候 性脳梗塞を含めて検討することは，その病態（広範 PVH は虚血之関連, 痴呆は加齢に伴ら皮質萎縮と関 連など）を知るらえで重要と考えられる。

\section{6. 脳梗塞の再発が脳循環代謝に及ぼす影響につい} ての検討

秋田県立脳血管研究センター神経内科

$$
\text { 佐藤 雄一, 長田乾, 平田温 }
$$

目的：最近，脳梗塞の再発を繰り返すことにより多 発梗塞性痴呆に陥る症例が増加している。その病態に 迫るために, 脳梗塞の再発が病巣以外の脳の循環代謝 に対して及ぼす影響を明らかにすることを目的とし て，今回の検討を行った。

方法：対象は脳梗塞を再発し，それぞれの発作後に ポジトロンCTを用いて脳循環代謝を測定し得た 3 例 である，脳循環代謝の測定は ${ }^{15} \mathrm{O}$-steady-state 法にて 行い,脳血流量 $\mathrm{CBF}$ および脳酸素消費量 $\mathrm{CMRO}_{2}$ を求 めた。脳梗塞の非再発例においても再発群と同じ期間 を経過した時期に同様の測定を行い，比較の対照とし た。

結果：再発群の症例 1 は左脳幹のラクナ梗塞で初発 し，12力月後に右中大脳動脈領域の広範な梗塞を再発 した．症例 2 は左側の帯状回から脳梁にかけての小梗 塞で初発し，47カ月後に同側の放線冠，前頭葉白質， 頭頂葉皮質および白質に脳梗塞を再発した。症例 3 は 左後頭葉の中等大の出血性梗塞の19力月後, 対側の小 脳半球に梗塞を発症した。非再発群 3 例の病巣は，そ れぞれ左頭頂葉の中等大の梗塞，左の頭頂葉と側頭葉 の中等大の梗塞，打よび左放線冠の小梗塞である，以 上の再発群と非再発群の脳循環代謝所見を比較する と, 天膜上に再発した場合, 病側大脳半球で X 線 CT あるいは MRI 上異常を認めない部位においても $\mathrm{CBF}$ および $\mathrm{CMRO}_{2}$ の著明な低下を認めた。対側半球にお いても影響を認め, その傾向は $\mathrm{CMRO}_{2}$ より $\mathrm{CBF}$ にお いて著明であった。一側小脳半球に梗塞を再発した場 合には, 対側の小脳半球や脳幹の $\mathrm{CBF}$ おょび $\mathrm{CMRO}_{2}$
の低下を認めた。また，天膜上構造に対しても影響を 及ぽし，CBFにおいてより顕著であった。

結論：脳梗塞の再発を繰り返すことにより病巣以外 の広範な領域においても循環代謝が障害を受けること が明らかとなり，このことは多発梗塞性痴呆に至る過 程を考觉るらえで興味深い。

97. 疫学的対照群 9 年間（1982～1991）における血 清脂質推移の統計学的考察 (I )

東邦大医一内 ${ }^{1)}$, 同 $\mathrm{ME}^{2)}$, 文部省統数研 ${ }^{3)}$, 動脈硬化疫学 ${ }^{4)}$, 東邦大医臨床生理機能学 ${ }^{51}$

$\begin{array}{lrrr}\text { 荒井 } & \text { 一歩, 森下 } & \text { 健 }^{1)} \text { 高山 } & \text { 吉隆 }{ }^{21} \\ \text { 駒澤 } & \text { 勉 }^{3} \text { 鈴木 } & \text { 腎二 }{ }^{4)} \text { 八鉢 } & \text { 恒芳 } \\ \text { 森 } & \text { 祐輔, 白井 } & \text { 厚治, 荒井 } & \text { 親雄 } \\ \text { 長谷川元治 }{ }^{5)} & & \end{array}$

疫学的対照群，前後 9 年間（1982１991）における 血清脂質（総コレステロール TC，中性脂肪 TG）を分 析し，性別，年代別， 2 期間別平均推移，ならびに閾 值設定による異常発生率を検討した結果，興味ある成 績をえたので報告する。

対象：対象は都市部居住者, 年齢 20 代 70 代, 総数 98,579 例，男 71,138 例，女 27,441 例である. 又本対象 群は動脈硬化症疾患, 特に高脂血症の既往ならびに現 病歴を有しない群でこれを対照群とした。

方法：1982〜1985までを A 群, 1988〜1991までを B 群とし, 分析した TC, TG の性別, 年代別傾向を検索 した後，A，B群を対比した。ささらに閾值を TC 220 , $260 \mathrm{mg} / \mathrm{d} l, T G 150,300 \mathrm{mg} / \mathrm{d} l$ とし, 各々異常発生率 （高脂血症）を同様検索，対比した。

成績：1. B 群での TC 性別, 年代別傾向は20～50代 まで増加（180～199），以後不変（男），20６0代まで 増加（174～217）以後不変（女）であった．又男20〜40 代は女に比し，女50～70代は男に比し有意の高値を示 した。

2. B 群 TG は20～40代まで増加（116～156）, 以後 低下(男), $20 ６ 0$ 代まで増加(71～127)，以後低下(女) となった．又いずれの年代共男が高値を示したが，加 齢により差は僅少となった。

3. 上記 1，2での A，B 群対比では性別, 年代別共 $\mathrm{B}$ 群が低值であった。

4. $\mathrm{TC}$ の閾值を $220 \mathrm{mg} / \mathrm{d} l$ とすると B 群の男 19 20\%, 女 35 39\%(50代以上)が異常, TG $150 \mathrm{mg} /$ $\mathrm{d} l$ では男24３3\%女18～25\%が異常となった。

5. 同様 $\mathrm{TC} 260 \mathrm{mg} / \mathrm{d} l$ で男 $2.5 \sim 3.2 \%$, 女 
7.2 8.1\%が異常であった. TG $300 \mathrm{mg} / \mathrm{d} l$ で男 $3.5 \sim 6.7 \%$ ，女2.1 2.5\%が異常であった。

6. 上記 4,5 について A, B 群を対比すると, B 群 が性別，年代別全般にわたり低率であった。

98. アルコール㩒取量と血清脂質およびインスリン 値との関連：久山町研究

九州大第二内科

加藤 功, 上田 一雄, 清原 裕

大村 隆夫, 岩本 廣満, 中山 敬三

大森将, 野見山賢介, 吉武 毅人

藤島 正敏

目的：適量のアルコール摂取は, 脂質代謝を改善す るといわれているが，その機序は必ずしも明らかでは ない，一方，アルコールはインスリン抵抗性を是正し て血清脂質に影響するといら説がある。そこで，福岡 県粕屋郡久山町の一般住民の断面調査成績を用いて, アルコール摂取の血清脂質に与兄る影響が，血清イン スリン值（IRI）を介するか否かを検討した。

対象と方法：1988年の久山町成人検診を受診した満 40 歳から79歳の男性 1,112 名の 5ち, $75 \mathrm{~g}$ 経口糖負荷試 験未受検者35名と糖尿病と判定された139名を除いた 934名を解析の対象とした。総コレステロール（TC） と中性脂肪（TG）は酵素法で, HDL コレステロール （HDLC）は沈殿法で測定した. LDL コレステロール (LDLC) は Friedewald の式から算出した。動脈硬化 指数 (AI) は (TC-HDLC)/ (HDLCで算出した. IRI は空腹時および糖負荷後120分で採血しRIA 法で測定 し，解析にはその和を用いた。飲酒量は一日あたりの 日本酒量に換算し 5 階級に分けた。交絡因子として年 齢, Body mass index, Waist-hip ratio, 契煙習慣, 身 体活動度, Impaired glucose tolerance, 収縮期血圧を 取り上げた，対象を 60 歳未満と以上の二群に分け，飲 酒と血清脂質の関係に及ぼす IRI 值の影響を重回帰分 析により検討した。

結果：1. IRI 值は飲酒量の上昇とともに有意に低下 したが，血糖値は飲酒量との間に一定の傾向を認めな かった。飲酒量の上昇と共にインスリン抵抗性が改善 していることが示唆された。 2. HDLC 值は, 飲酒量の 増加と共に有意に上昇し，LDLC おょび AI は有意に 低下した。TGは，飲酒量に対してU-shape の傾向が あった．3．脂質を目的変数とした重回帰分析におい て，説明変数に IRI を追加しても，HDLC, LDLC, AI に対する飲酒の重回帰係数は $1 \%$ から $13 \%$ の低下にと
どまった，以上の結果は壮年群でも高齢群でも変わら なかった。

結論：飲酒の血清脂質代謝に及ぼす影響は，主に血 清インスリン值を介さない別の機序によると考兄られ た。

99. 老年期に血清総コレステロール值は低下するか 都老人医療センター研究検査科 ${ }^{1)}$, 内分泌科 ${ }^{21}$ 佐藤 忠弘 ${ }^{1)}$ 井上潤一郎 ${ }^{2}$ 荒木 厚 ${ }^{2}$ 服部 明德 ${ }^{2}$ 井藤 英喜 ${ }^{2}$

横断調査では老年期にはヒトの血清総コレステロー ル(TC)值は年齢と共に低下することが示されている。 しかし, 縦断調査による TC 值の加齢変化についての 報告は少ない，そこで我々は1989年から1992年まで継 続して TC 値を測定出来た地域在住の老年者を対象に 老年期における TC 值の変動について検討したので報 告する.

対象と方法：対象は東京都足立区在住で健和会柳原 病院に打ける高齿者健康診查を89年から92年まで継続 して受診した 65 歳以上の老年者 648 例で男性 224 例, 女 性424例. 92年の健康診查末でに抗高脂血症剂の服用歴 のある者は除外した。検定には paired t-test,

ANOVA，重回帰分析を用いた。

結果：1989年の TC 值は男性で平均 $180 \pm 32 \mathrm{mg} / \mathrm{d} l$ (範囲81 $276 \mathrm{mg} / \mathrm{d} l, 75 \%$ tile $201 \mathrm{mg} / \mathrm{d} l$ ), 69 歳以下 $183 \pm 29 \mathrm{mg} / \mathrm{d} l, 70$ 歳台 $180 \pm 29 \mathrm{mg} / \mathrm{d} l, 80$ 歳以上 $171 \pm$ $37 \mathrm{mg} / \mathrm{d} l$, 女性ではそれぞれ $206 \pm 33 \mathrm{mg} / \mathrm{d} l(112 \sim 315$ $\mathrm{mg} / \mathrm{d} l, 229 \mathrm{mg} / \mathrm{d} l), 209 \pm 33 \mathrm{mg} / \mathrm{d} l, 208 \pm 32 \mathrm{mg} / \mathrm{d} l$, $198 \pm 33 \mathrm{mg} / \mathrm{d} l$ であり, 綎断調査では男女とも年齢と 共に低下寸る傾向にあり, 男性では67歳以上, 女性で は70歳以上で最も有意な值線回帰式が得られた。 89 年 と92年の TC 值を比較すると, paired t-testでいずれ の間にも有意差は認めなかった。 3 年間の $\mathrm{TC}$ 値の変 化量 $[92 \mathrm{TC}-89 \mathrm{TC}]$ は -101 から $+109 \mathrm{mg} / \mathrm{d} l$, 平均 はー $1 \pm 25 \mathrm{mg} / \mathrm{d} l$ であり, これを従属変数として重回 帰分析を行ったところ, 男性では年齢に67歳以上で弱 いが有意な相関関係を認めた。女性では年齢は有意で はなかった。

まとめ： 3 年間の追跡調査でプレリミナリ一ではあ るが，老年期における TC 值の経年变化について検討 した. cross sectional には老年期の TC 值は年齢と共 に低下または低下傾向にあるが，追跡調查では低下し なかった。しかし, 男性では70歳台以降 TC 值は低下 する可能性があり, 今後更なる追跡, 対象数を増やし 
ての検討が必要と考えられた。

100. 家族性高コレステロール血症へテロ接合体患者 のインスリン感受性

\section{東海大大磯病院内科}

山口 雅臣，小林 俊雄，山口浩 坂根 浩弥，小沢 秀樹，本間 康彦

目的：家族性高コレステロール血症 $(\mathrm{FH})$ へテロ接 合体患者に OGTTを行い，インスリン感受性を検討 した。

方法： 7 例の未治療 $\mathrm{FH}$ 患者, 5 例の薬物治療中の FH 患者が対象であった。インスリン感受性を高める fibrate 服用中の患者は除外した。 $75 \mathrm{~g}$ OGTTを行い PG，IRI を測定した。

結果: 未治療 $\mathrm{FH}$ 患者は年齢 $34.6 \pm 13.2$ 歳, $\mathrm{BMZ}$ $21.9 \pm 2.0 \mathrm{~kg} / \mathrm{m}^{2}$, TC $333.8 \pm 45.8 \mathrm{mg} / l$, LDL-C $268.0 \pm 28.3 \mathrm{mg} / \mathrm{d} l$, HDL-C $41.6 \pm 13.0 \mathrm{mg} / \mathrm{d} l$, アポ B $164.5 \pm 21.5 \mathrm{mg} / \mathrm{d} l$ ，アキレス腱厚 (XP) $14.3 \pm 5.2$ $\mathrm{mm}$ であった。治療 $\mathrm{FH}$ 患者は年齢54.4 1 16.4歳, BMI $22.5 \pm 2.4 \mathrm{~kg} / \mathrm{m}^{2}$, TC $225.6 \pm 27.4 \mathrm{mg} / \mathrm{d} l$, LDLC $174.6 \pm 41.7 \mathrm{mg} / \mathrm{d} l$, HDL-C $28.6 \pm 9.2 \mathrm{mg} / \mathrm{d} l$, アポ B $101.0 \pm 13.1 \mathrm{mg} / \mathrm{d} l$ ，アキレス腱厚 $16.5 \pm 5.7 \mathrm{~mm}$ で あった. OGTTのPGは全体では，負荷前83.2 210.1 $\mathrm{mg} / \mathrm{d} l$, 負荷 30 分 $139.2 \pm 28.1 \mathrm{mg} / \mathrm{d} l, 60$ 分 $136.7 \pm 52.5$ $\mathrm{mg} / \mathrm{d} l, 120$ 分 $113.9 \pm 33.0 \mathrm{mg} / \mathrm{d} l, 180$ 分 $81.6 \pm 27.7$ $\mathrm{mg} / \mathrm{d} l$ であり, 未治療, 治療群で差は認められなかっ た. IRIは, 全体で, 負荷前 $5.9 \pm 4.5 \mu \mathrm{U} / \mathrm{m} l$, 負荷 30 分 $57.1 \pm 42.8 \mu \mathrm{U} / \mathrm{m} l, 60$ 分 $53.9 \pm 28.1 \mu \mathrm{U} / \mathrm{m} l, 120$ 分 $53.6 \pm 46.4 \mu \mathrm{U} / \mathrm{m} l, 180$ 分 $22.3 \pm 17.8 \mu \mathrm{U} / \mathrm{m} l$ と, 負荷 後30から120分まで高値が持続した。 IRI 頂值 $100 \mu \mathrm{U} /$ $\mathrm{m} l$ 以上は 12 例中 3 例であった. IRI 頂値 $50 \mu \mathrm{U} / \mathrm{m} l$ で 120 分値 $50 \mu \mathrm{U} / \mathrm{m} l$ または 120 分值 $50 \mu \mathrm{U} / \mathrm{m} l$ 以上の高 インスリン血症患者は 12 例中 9 例であった。

結論：FH ヘテロ接合体患者では OGTT 時, 血糖曲 線は正常であったが, 高インスリン血症が認められ, インスリン感受性低下が示唆された。

101. 加龄と必須脂肪酸レベルとの関係について

$\begin{array}{ll}\text { 宮城県鶯沢町医院 } & \text { 高橋龍太郎 } \\ \text { 岩手県沢内病院 } & \text { 佐々木鉄矢 } \\ \text { 老人医療センター内分泌 } & \text { 井藤 英喜 } \\ \text { 老人研社会福祉 } & \text { 出雲 祐二 }\end{array}$

必須脂肪酸の加齢変化を検討する場合問題となる点 は，（1）食事中の脂質の影響，（2）広い年齢層につい
ての検討，（3）合併疾患の影響，であると思われる。 我々は既に，一年以上健康老人ホームに居住し同じ給 食を摂っている63歳から97歳の高齢者277名について 血中脂肪酸分析を行い，加齢と共に $\mathrm{n}-6$ 系必須脂肪酸 が低下することを示した（J. Nutr. Sci, Vitaminol. $37 ； 401 ， 1991)$.この時の調査では(2)の条件について は不十分と思われた。 三条件をすべて満足することは 実際上不可能と思われるが，今回，比較的閉鎖的食・ 住環境下にある地域の人間ドック時血清試料を利用で きる機会を得たのでその成績を報告する。

対象は岩手県沢内村在住の35歳から70歳 (平均53歳) の成人366名 (男性151名女性 215 名) で， 3 年毎の総合 成人病検診 (人間ドック) 受診時の血清試料を用いて TLC, GLCにてリン脂質中の脂肪酸分析を行った（分 析は Efamol Research Institute, Nova Scotia, Canada にて実施).

その結果， 46 -デサチュラーゼ (D6D) の代謝物であ るジホモー $\gamma$-リノレン酸とアラキドン酸は年齢と有意 の負の相関を，エイコサペンタェン酸は有意の正相関 を示した。 D6D 活性の指標として D6D に代謝された $\mathrm{n}-6$ 脂肪酸の和とリノール酸の比をとると, 年齢と有意 の負の相関関係が得られた。一方, n-6脂肪酸の総和自 体は加齢变化を認めなかった。

年齢を基準として全体を 5 群に分け一元配置分散分 析を行うと, 前述の D6D 活性指標は60歳以上の群で有 意に低下し我々の既報の成績と一致した。

細胞膜の重要な成分であるアラキドン酸やプロスタ グランジン $\mathrm{E}_{1}$ の前駆体であるジホモ・ $\gamma$-リノレン酸は 加齢と共に減少し，その原因として必須脂肪酸合成の 律速酵素である D6D 活性の低下が示唆された。

\section{EPA の血清 HDL 覀分画レベルに対する影響} 東海大大磯病院内科

$\begin{array}{lrrr}\text { 本間 } & \text { 康彦, 山口 } \text { 雅臣, 小林 俊雄 } \\ \text { 山口 } & \text { 浩, 坂根 浩弥, 小沢 秀樹 } \\ \text { 三神 } & \text { 美久, 三神 美和 } & \end{array}$

目的：EPAの血清 HDLレベルに対する影響につ いて議論が多い.HDL 亜分画レベルに対する影響を EPAの投与量との関連で検討した。

方法：EPA エチルェステルを12週間 3 群に投与し た. $\mathrm{A}$ 群 $(300 \mathrm{mg} /$ 日群, $\mathrm{N}=14$, 年齢 $61.2 \pm 11.0$ 歳),

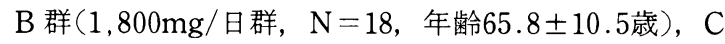
群 $(2,700 \mathrm{mg}$ /日群, $\mathrm{N}=19$, 年齢 $53.4 \pm 18.7$ 歳) の 3 群で比較した。血清リポ蛋白の亜分画は超遠心法, gra- 
dient PAGE 法で行った。

結果：VLDL-C 值はA 群で $22.1 \pm 14.6 \mathrm{mg} / \mathrm{d} l$ から $16.5 \pm 9.8 \mathrm{mg} / \mathrm{d} l$ に, B 群 で $19.5 \pm 14.3 \mathrm{mg} / \mathrm{d} l$ から $13.5 \pm 6.5 \mathrm{mg} / \mathrm{d} l$ に, C 群 で $24.6 \pm 17.9 \mathrm{mg} / \mathrm{d} l$ から $15.4 \pm 14.1 \mathrm{mg} / \mathrm{d} l$ と変化し, C 群でのみ有意の低下を 認めた $(\mathrm{p}<0.01)$. IDL-C 值は A 群 $12.5 \pm 4.3 \mathrm{mg} / \mathrm{d} l$ から $14.9 \pm 5.1 \mathrm{mg} / \mathrm{d} l, \mathrm{~B}$ 群では $12.5 \pm 3.9 \mathrm{mg} / \mathrm{d} l$ から $14.7 \pm 6.5 \mathrm{mg} / \mathrm{d} l, C$ 群では $13.1 \pm 7.2 \mathrm{mg} / \mathrm{d} l$ から $11.4 \pm 6.0 \mathrm{mg} / \mathrm{d} l$ へと有意の変化は認められなかっ

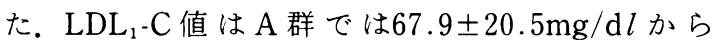

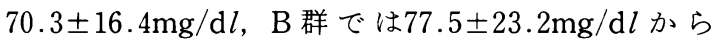
$73.9 \pm 22.7 \mathrm{mg} / \mathrm{d} l, C$ 群では82.7土29.4mg/d $l$ から $75.5 \pm 23.0 \mathrm{mg} / \mathrm{d} l$ へと, EPA 投与量の増加とともに $\mathrm{LDL}_{1}-\mathrm{C}$ 值が低下する傾向が認められたが有意の変化

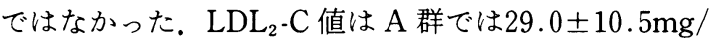

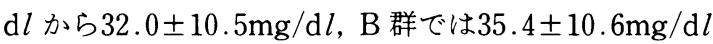
から $34.8 \pm 14.3 \mathrm{mg} / \mathrm{d} l, C$ 群 $33.1 \pm 11.1 \mathrm{mg} / \mathrm{d} l$ から $38.3 \pm 15.7 \mathrm{mg} / \mathrm{d} l$ へと, C 群でのみ増加傾向が認めら れたが有意の変化ではなかった. $\mathrm{HDL}_{2}-\mathrm{C}$ 値は $\mathrm{A}$ 群で

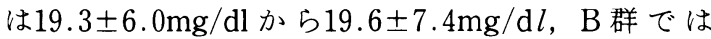
$18.1 \pm 7.4 \mathrm{mg} / \mathrm{d} l$ から $19.1 \pm 7.9 \mathrm{mg} / \mathrm{d} l, C$ 群では $16.2 \pm 6.8 \mathrm{mg} / \mathrm{d} l$ から $17.1 \pm 7.2 \mathrm{mg} / \mathrm{d} l$ へと 3 群とも 変化が認められなかった. $\mathrm{HDL}_{3} \cdot \mathrm{C}$ 値は $\mathrm{A}$ 群では $20.6 \pm 3.0 \mathrm{mg} / \mathrm{d} l$ から $22.5 \pm 3.8 \mathrm{mg} / \mathrm{d} l$, B 群では $21.9 \pm 4.5 \mathrm{mg} / \mathrm{d} l$ から $22.1 \pm 12.6 \mathrm{mg} / \mathrm{d} l$, C群では $19.6 \pm 3.3 \mathrm{mg} / \mathrm{d} l$ から $19.6 \pm 3.7 \mathrm{mg} / \mathrm{d} l$ へと変化が認 められなかった. gradient PAGEでも HDL 亜分画分 布に変化は認められなかった。

結論：EPA-Eは2,700mg/日投与においてのみ, 血 清 ULDL 量が減少したが, HDL 亜分画レベルに変化 は認められなかった。

\section{3. 低比重リポ蛋白の被酸化性に関する研究ープロ} ブコール濃度と共役ジェン生成抑制についてー

防衛医大第 1 内科

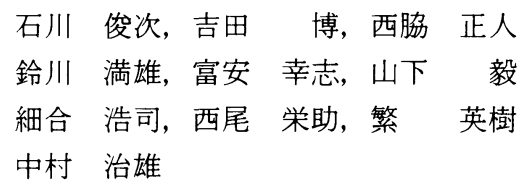

はじめに：粥状動脈硬化発症に低比重リポ蛋白 (LDL) の増加のみならずその酸化変性が関与してい る. 抗高脂血薬のプロブュール $(\mathrm{P})$ は抗酸化作用を有 寸ることが知られるが, その血中濃度と効力との関係, ビタミン $\mathrm{E}, \beta$ カロチンなどの他の抗酸化物の濃度に
及ぼす影響について十分明らかにされていない。 対象と方法：18人の外来高コレステロール (C) 血症 患者 $(\mathrm{M} \pm \mathrm{SD}, 273 \pm 57 \mathrm{mg} / \mathrm{d} l)$ に $\mathrm{P}$ を500ないし750 $\mathrm{mg}$ /日投与し, 前, 4,8週で EDTA 採血, LDL（比重 1.019〜1.063）を超遠心法で分離した。脂質は酵素法， 蛋白は Lowry 法, ビタミン $\mathrm{E}, \beta$ カロチンは液体クロ マトグラフィー, 脂肪酸はガスクロマトグラフィーで 測定し, LDL 被酸化性は $\mathrm{Cu}^{++}$添加後の共役ジェン生 成の lag timeにより評価した。

結果：P投与後，総 C 値は 4 週 $16 \%, 8$ 週10\%有意 に低下した. LDL-C は 4 週， 8 週で $9 \% ， 3 \%$ 低下し $(\mathrm{p}<0.05), \mathrm{LDL}$ の脂質/蛋白比は $\mathrm{P}$ 投与前の 2.6 から 8 週の 2.3 に減少した $(\mathrm{p}<0.01)$. LDL の P 濃度は個 人差が大きく， 4 週， 8 週の平均値では有意差は見ら れなかった. 共役ジェン生成の lag time の平均は P 投 与前，4，8 週で，それぞれ，75，155，156分で $\mathrm{P}$ 投 与により約 2 倍延長した $(\mathrm{p}<0.01)$. lag time の増加 と LDL P 濃度には正相関が認められた $(\mathrm{p}<0.01) . P$ 投与前後, $\mathrm{LDL}$ のビタミン $\mathrm{E}, \beta$ カロチン濃度, 脂肪 酸組成には有意な変化は見られなかった。

結論：他の抗酸化物質濃度に影響することなく, $\mathrm{P}$ は LDL の酸化を強力に抑制し, その効力は濃度に依 存していた.

104. 老化現象に関する研究一第83報一Bezafibrate 投与の血清脂質リポ蛋白分画への影響

国療南岡山病院内科

$\begin{array}{lrrr} & \text { 三島 } & \text { 康男, 木畑 } & \text { 正義 } \\ \text { 国立岡山病院内科 } & \text { 石岡 } & \text { 達司 } \\ \text { 岡山大第二内科 岡田 康司, 神坂 } & \text { 謙 } \\ & \text { 藤原みち子, 木村 } & \text { 郁郎 }\end{array}$

目的：Bezafibrate (以下 Beza)の血清脂質, アポ蛋 白に対する効果は諸家により報告され臨床にも広く用 いられているが, リポ蛋白分画への関与についての報 告は極めて少ない。我々はBeza 投与による血清脂質 およびリポ蛋白分画に関する検討を行い興味ある結果 を得たので報告する。

対象および方法：外来通院中の高脂血症患者 12 名 (IIa 4 名, IIb 8 名) に Beza $400 \mathrm{mg} /$ 日投与を行い, 投与前， 2 週， 4 週， 8 週において血清脂質，アポ蛋 白を測定した。リポ蛋白分画は polyacrylamide gel （PAG）電気泳動を簡便に行える Lipophor systemに より行った.

結果：Beza 投与により 4 週, 8 週後には TC, TG, 
アポ B , C2，C3，Eの有意な低下と HDL-c，アポ A 1, $\mathrm{A} 2, \mathrm{~A} 1 / \mathrm{B}$ 比の有意な上昇がみられた。なかでも HDL-c，アポA2, B, A1/B 比の変動がすでに 2 週後 よりみられた事は興味深い.リポ蛋白分画は Lipophor により得られた LDL 分画を 4 型に分類し検討した。 すなわち LDL 分画が左右対象で幅の狭いもの（Symmetrical $=\mathrm{S}$ ), 左右非対象のもの (Asymmetrical = A), 結節を有するもの (Nodular $=\mathrm{N}), \mathrm{LDL}$ 分画の形 の著明に崩壊したもの（Disrupted=D）に分類した。 $\mathrm{S}$ 型は脂質正常者に高頻度にみられ， A, N , D の順に リポ蛋白としての異常が増すものと考光られ, 特に $\mathrm{N}, \mathrm{D}$ 型は midband 陽性とみなされる. Beza 投与前は 1 例が $\mathrm{A}$ 型で他は $\mathrm{N}, \mathrm{D}$ 型であったが， 4 週後には $\mathrm{N}, \mathrm{D}$ 型は消失し (midband の改善と解釈する) $\mathrm{S}$ 型 2 例, $\mathrm{A}$ 型 6 例であったが 8 週後には $\mathrm{S}$ 型 5 例, $\mathrm{A}$ 型 4 例とさらに改善がみられた。これらのらち 2 週後に 判定し得た 5 例については $\mathrm{N}$ 型の 1 例のみが $\mathrm{N}$ のま まであり他は改善がみられた。 4,8 週後においても リポ蛋白分画の改善傾向は継続して観察された。

かかる成績は血清脂質の面だけでなく，TG richリ ポ蛋白の関与した動脈硬化促進作用を Beza が抑制す る可能性を示唆するものである.

\section{5. 老化現象に関する検討一第82報一FHにおける} プラバスタチンのアキレス腱黄色腫に対する影響

国立岡山病院 ${ }^{1)}$, 国療南岡山病院 ${ }^{2}$, 岡山大学 第 2 内科 ${ }^{3)}$

石岡 達司 ${ }^{11}$ 瀬崎 $\quad$ 達雄 $^{11}$ 三島 康男 ${ }^{21}$ 木畑 正義 ${ }^{2)}$ 神坂謙 ${ }^{3)}$ 岡田 康司 ${ }^{3)}$

藤原 久ち子 ${ }^{31}$

目的：高脂血症に対する薬物療法は動脈硬化の発症 進展を抑制する目的で行われているが, 薬剂効果の評 価を冠動脈造影のような観血的な検査で行うとすると 一般臨床では制約を受けることが多い。しかし，家族 性高コレステロール血症 (FH) では粥状硬化と同じ発 症機序を有するアキレス腱黄色腫に対する効果をみて 指標とすることが一部可能であるる。そこで, 最近臨 床応用になった HMG一 $\mathrm{CoA}$ 還元酵素阻害剂（HMGI)の $\mathrm{FH}$ に対する効果をアキレス腱黄色腫に対する影 響によって検討したので報告する。

方法：厚生省特定疾患原発性高脂血症調査研究班の 家族性高コレステロール血症の診断基準を満たした男 性 2 名，女性 20 名の 22 名（平均年齢 $57 \pm 8$ 歳）を対象 とした。治療はプラバスタチン $(10 \mathrm{mg} /$ 日)の単独投与
( $\mathrm{M}$ 群)，プロブコール $(500 \mathrm{mg} /$ 日) 単独投与 ( $\mathrm{P}$ 群) および併用投与群(MP群)に分類して行ったがそれぞ れの症例数は 9 名， 3 名，10名であった。アキレス腱 の測定は薬剤投与前と投与 15 から 18 力の間に軟線撮 影により㧍こない $0.5 \mathrm{~mm}$ 単位で表現した。

結果: 治療開始前の TC の平均は $\mathrm{M}$ 群 $281 \mathrm{mg} / \mathrm{d} l$, $\mathrm{P}$ 群 $284 \mathrm{mg} / \mathrm{d} l, M P$ 群 $302 \mathrm{mg} / \mathrm{d} l$ と群間に差は認めら れなかった。アキレス腱肥厚值は $\mathrm{M}$ 群 $9.5 \mathrm{~mm}, \mathrm{P}$ 群 $9.4 \mathrm{~mm}, \mathrm{MP}$ 群 $10.7 \mathrm{~mm}$ で MP 群が有意に $(\mathrm{p}<0.01)$ 高值であった。治療により TC は M 群10\%, P 群18\%, MP 群15\%の低下が認められたが，フキレス腱肥厚值 は M 群 $2.2 \mathrm{~mm}, \mathrm{P}$ 群 $2.3 \mathrm{~mm}, \mathrm{MP}$ 群 $1.6 \mathrm{~mm}$ 退縮した。

特に, P 群と MP 群においては治療による LDL-C の低下量とアキレス腱肥厚の退縮長に正の相関が認め られた。

老年医学的意義：HMG-I のアキレス腱黄色腫に対 する長期の検討は少なく, 従って改めてその有用性が 認められた。しかも今回の結果から HMG-I は粥状硬 化進展抑制に有効な薬剂と思われた。

\section{6. 肥満度と Pravastatin の脂質代謝改善効果}

日本大第 2 内科1)（駿河台，板橋病院）, 東松 山市民病院 ${ }^{2}$, 銚子市立総合病院 ${ }^{3)}$, 東京共済 病院 ${ }^{4)}$

増㴊 和夫 ${ }^{1)}$ 八木 洋 ${ }^{11}$ 上西 壮 ${ }^{11}$ 鈴木裕太郎2) 東野 廣也 ${ }^{3)}$ 河村 博1) 橋田 潤4) 小林 良子 ${ }^{11}$ 梶原 長雄 ${ }^{11}$ 上松瀬勝男 ${ }^{1)}$

目的：中高年齢層における Pravastatin 投与前の肥 満の程度が脂質代謝改善効果にいかなる影響を及ぼす か明らかにする目的で本研究を行った。

対象：血清総コレステロール (TC) が $220 \mathrm{mg} / \mathrm{d} l$ 以 上の 130 例（61.4 1 10.2歳, 男性36例, 女性94例）で, Body Mass Index (B.M.I.) が20\%以上の肥満群38例, 非肥満群92例である。重篤な肝, 腎疾患例, 脂質代謝 に影響を及ぼすと考えられる基礎疾患を有する症例お よび多量飲酒者は除外した。

方法：Pravastatin 10mg/日を6 力月間投与し，投 与前, 1 力月, 3 力月, 6 力月後に TC, HDL-C, 中 性脂肪 (TG), LDL-C, Apo-AI, Apo-B, Apo-CII, TC/HDL-C 比について測定した。成績は mean \pm SE で示した。

結果：肥満群は TC, TG, LDL-C, Apo-B, Apo-CII, $\mathrm{TC} / \mathrm{HDL} \cdot \mathrm{C}$ 比は 1 力月投与より有有意に低下し， 3 
カ月, 6 力月後とも前值に比し有意に低值であった。 HDL-C 3 力月以後有意な増加が観察されたが Apo-AI K明らかな変化は観察されなかった。非肥満 群では TC, LDL-C, Apo-B, TC/HDL-C 比は 1 カ月 後より低下し， 3 力月， 6 力月後とも前值に比し有意 に低值であった. HDL-C は 1 カ月後より増加し, 3 力 月, 6 カ月後とも有意に高值であったが, TG, Apo-AI, Apo-CII には明らかな変化は認められなかった。

まとめ：肥満の程度に関係なく Pravastatin は中高 年齢層のコレステロール代謝を改善したが，肥満群は 非肥満群に比し投与前値の HDL-C, Apo-AI 值は低値 を示し, HDL-C の増加も遅延した。非肥満群の TG は 投与前值が低值であった。肥満は低 HDL-C 血症の主 たる原因であることが指摘されて打り，肥満の程度に より Pravastatin の HDL-C 増加作用は影響されるも のと推測された。

107. 高脂血症を合併した正常血圧例および高血圧例 における Pravastatin の効果

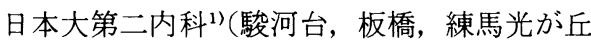
病院），東松山市民病院 ${ }^{21}$ ，銚子市立総合病 院 ${ }^{3)}$, 東京共済病院 ${ }^{4}$

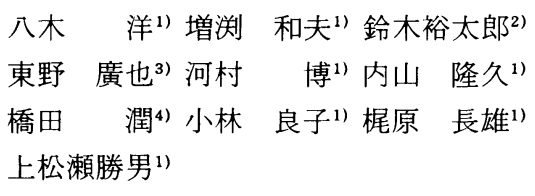

目的：近年，高血圧症に伴う脂質代謝異常が注目さ れて来ており，本研究は中高年齢層において高脂血症 を合併した高血圧症に Pravastatin がいかなる脂質代 謝改善効果をもたらすか, 明らかにする目的で行った。

対象：血清総コレステロール (TC) が $220 \mathrm{mg} / \mathrm{d} l$ 以 上の 100 例(男性 27 例, 女性73例), 正常血圧群27例(平 均年齢59 9 歳), WHO 分類のIII期の本態性高血圧群 63 例 (平均年齢 $63 \pm 10$ 歳) である。両群とも WHO 分 類の IIa, IIb 型高脂血症である. 重篤な肝, 腎疾患例, 脂質代謝に影響を及ぼすと考えられる基礎疾患を有す る症例および多量飲酒者は除外した。

方法：Pravastatin 10〜20mg/日を 6 力月間投与 し, 投与前, 1 力月， 3 力月， 6 力月後に TC, HDL-C, 中性脂肪(TG), LDL-C, Apo-AI, Apo-B, Apo-CII, TC/HDL-C 比を測定した.

結果：正常血圧群では TC, TG, LDL-C, Apo-B, TC/HDL-C 比は 1 力月後上り有意に低下し, HDL-C は 6 カ月後より有意に増加した。 6 力月後に Apo-AI
の増加, Apo-CII の有意な低下が認められた。高血圧群 に扔いては, TC, LDL-C, Apo-B, Apo-CII, TC/ HDL-C 比の有意な低下を, HDL-C の有意な増加を 1 カ月後より認めた。 TG, Apo-AI には明らかな変化は 観察されなかった。

まとめ：Pravastatin は高血圧の有無に関係なく， 中高年齢層のコレステロール代謝を改善し, 動脈硬化 指数を低下し，高脂血症を合併した高血圧症を伴う動 脈硬化病変の進展抑制に有用であると考えられた。し かしながら, 高血圧群においては TGには明らかな変 化は認められなかった。この機序として併用降圧剤の 影響, 高血圧症と Insulin 抵抗性の増加, 収縮期血圧と TGには負の相関が存在するとも指摘されており，一 元的に説明することは困難と考えられた。

\section{Pravastatin 効果と喫煙}

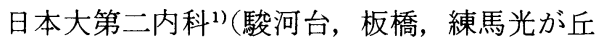
病院), 東松山市民病院 ${ }^{2}$, 銚子市立総合病 院 ${ }^{3)}$, 東京共済病院 ${ }^{4)}$

渡辺 高祥 ${ }^{1)}$ 八木 洋 ${ }^{11}$ 増㴊 和夫 ${ }^{11}$ 鈴木裕太郎 ${ }^{2)}$ 東野 廣也 ${ }^{3)}$ 内山 隆久 ${ }^{11}$ 河村 博1) 橋田 潤4) 梶原 長雄 ${ }^{11}$ 上松瀬勝男 ${ }^{11}$

目的：Framingham studyによると喫煙者の HDL-C は低值を示すことが指摘されており, 中高年 齢層に拈ける高脂血症を伴う契煙者と非契煙者の HDL-C 代謝に Pravastatinがいかなる影響を及ぼす か明らかにする目的で本研究を行った。

対象：血清総コレステロール (TC) $220 \mathrm{mg} / \mathrm{d} l$ 以上 の 130 例, 平均年齢 $61.4 \pm 10.2$ 歳, 男性 36 例, 女性 94 例 中, 喫煙群13例, 非喫煙群109例である。重篤な肝, 腎 疾患例，脂質代謝に影響を及ぼすと考兄られる基礎疾 患を有する症例および多量飲酒者は除外した。

方法：Pravastatin 10～20mg/日を6 力月間投与 し, 投与前, 1 力月, 3 力月, 6 力月後に TC, HDL-C, 中性脂肪(TG), LDL-C, Apo-AI, Apo-B, Apo-CII, TC/HDL-C 比を測定した。

結果：喫煙群は TC, LDL-C, Apo-B, TC/HDL-C 比は 1 力月後より有意に低下したが, HDL-C の有意 な増加, TG の有意な低下は 6 カ月後に認められた。 Apo-AI, Apo-CII には明らかな変化は観察されなかっ た。非牟煙群は 1 力月後上り TC, TG, LDL-C, Apo-B, Apo-CII, TC/HDL-C 比の有意な低下, HDL-C の有意 な増加が観察された。Apo-AIには明らかな変化は認 
められなかった。

まとめ: Pravastatin の HDL-C 上昇の機序は, コレ ステロール転送の acceptor としての LDL-C が減少 することによると考えられている。本剤は喫煙の有無 に関係なく中高年齢層の LDL-C を低下させたが，哭 煙群は非契煙群に比し, HDL-C の増加効果が遅延し た。尚, 契煙群は非契煙群に比し投与前の HDL-C, Apo-AI は低值であった。

\section{9. 高齢者高脂血症に対するシンバスタチンの効果} 千葉大第二内科, 松戸市立病院内科*

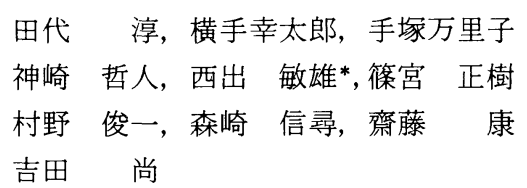

目的：HMG CoA 還元酵素阻害薬シンバスタチン の高齢者に対する有効性と安全性を明らかにする.

対象と方法：65歳以上の高齢者高コレステロール血 症 $(220 \mathrm{mg} / \mathrm{d} l$ 以上) 患者 21 例（男：女 $=4: 17,70 \pm$ 4 歳）と60歳以下の壮年者高コレステロール患者 27 例 （男：女 $=7 ： 20 ， 53 \pm 6$ 歳）に対しシンバスタチン 5 $\mathrm{mg} /$ 日を 12 週間経口投与し, 前後の血清脂質, リポ蛋白 （a）（Lp（a））およびュルチゾール值を比較した.

結果：高齢者群において血清総コレステロール (TC) 值 $23 \%(275 \pm 28 \mathrm{mg} / \mathrm{d} l \rightarrow 209 \pm 26 \mathrm{mg} / \mathrm{d} l)$, LDL コレステロール (LDL-C) 值は $31 \%$ (195 $\pm 30 \mathrm{mg} /$ $\mathrm{d} l \rightarrow 130 \pm 23 \mathrm{mg} / \mathrm{d} l)$ の低下を認めた $(\mathrm{p}<0.001)$. 壮 年者群では TC 値が $19 \%(278 \pm 26 \rightarrow 227 \pm 28 \mathrm{mg} / \mathrm{d} l)$, LDL-C 值が $28 \% （ 194 \pm 33 \rightarrow 143 \pm 34 \mathrm{mg} / \mathrm{d} l)$ の低下を 認め, 高齢者群の TC 低下率は壮年者群に比し大きい 傾向であった $(\mathrm{p}<0.1)$. 中性脂肪 $(\mathrm{TG})$ 值と HDL ב レステロール(HDL-C) 値は変化を認めず(TG：153士 $85 \rightarrow 138 \pm 70 \mathrm{mg} / \mathrm{d} l$, HDL-C $: 49.9 \pm 11.1 \rightarrow 51.6 \pm$ $10.6 \mathrm{mg} / \mathrm{d} l$ ), 壮年者での成績 (TG : $158 \pm 101 \rightarrow 159 \pm$ $98 \mathrm{mg} / \mathrm{d} l$, HDL-C : $54 \pm 14 \rightarrow 55 \pm 13 \mathrm{mg} / \mathrm{d} l$ ) と同様で あった，Lp（a）值は全症例では軽度低下（13\%）を示 し $(\mathrm{p}<0.05), 40 \mathrm{mg} / \mathrm{d} l$ 以上の高值例で $26 \%(53 \pm 14$ $\rightarrow 39 \pm 14 \mathrm{mg} / \mathrm{d} l)$ の低下を認めた $(\mathrm{p}<0.05)$. コルチ ゾール值は変化がみられなかった。重篤な副作用は両 群で認められなかった。

結論：シンバスタチンは高齢者に対し，壮年者と同
じ用量用法で同等のコレステロール低下作用と安全性 を有することが示唆された。高 Lp（a）症例でシンバ スタチン投与により Lp（a）の低下が認められた.

\section{0. 高齢者高脂血症に対するプラバスタチン投与に} よる凝固線溶系およびLp（a）への影響 名古屋市厚生院内科

坂野 章吾, 新美 達司, 山本 俊幸 目的：高齢者高脂血症患者では凝固線溶系および血 管内皮細胞障害マーカーが異常值を認めるとともに, リポプロテイン（a）[Lp（a)］の高值を認め血栓準備 状態にあると考えられる。今回，我々は抗高脂血症剤 (プラバスタチン)の投与による凝固線溶系，血管内皮 細胞障害マーカーおよび Lp（a）に対する影響を検討 した.

対象, 方法：65歳以上 (平均 $77.8 \pm 8.3$ 歳) の高コレ ステロール血症 (T. Chol $240 \mathrm{mg} / \mathrm{d} l$ 以上) 患者で約 1 年間，継続してプラバスタチン $10 \mathrm{mg} / \mathrm{day}$ を投与でき た28例について投与前後での血清脂質值および各種凝 固線溶系，血管内皮細胞障害マーカー， Lp (a)を測定 し検討した。

結果：検查結果は各々, 投与前, 投与後で以下であっ た. T. Chol $(\mathrm{mg} / \mathrm{d} l)$ （投与前 $279.5 \pm 20.1$, 投与後 $221.2 \pm 28.0, \mathrm{p}<0.001), \mathrm{HDL}-\mathrm{C}(\mathrm{mg} / \mathrm{d} l)$ （前 $45.6 \pm$ 15.5 , 後 $48.7 \pm 18.0), \beta-\mathrm{LP}(\mathrm{mg} / \mathrm{d} l) （$ 前 $767 \pm 122$, 後533 $\pm 101, \mathrm{p}<0.001), \mathrm{TAT}(\mathrm{ng} / \mathrm{m} l)$ (前 $4.2 \pm 2.5$, 後7.1 \pm 9.7$), \operatorname{PIC}(\mu \mathrm{g} / \mathrm{m} l)$ (前 $1.1 \pm 0.6$, 後 $1.0 \pm 0.5$ ), D-dimer $(\mathrm{ng} / \mathrm{m} l$ ) (前 $203 \pm 185$, 後 $170 \pm 120, \mathrm{p}<0.05$ ), $\mathrm{TM}(\mathrm{ng} / \mathrm{ml})$ （前 $4.3 \pm 1.6$, 後 $4.2 \pm 1.5), \mathrm{vWF}: \mathrm{Ag}$ (\%)（前 $220 \pm 74$, 後 $216 \pm 62), \mathrm{Lp}(\mathrm{a})(\mathrm{mg} / \mathrm{d} l) （$ 前 $35.9 \pm 26.7$ ，後 $36.4 \pm 31.2 ）$ プラバスタチン投与によ り高齢者高脂血症患者は有意に T. Chol は低下を認め た. D-dimer は p<0.05で低下を認めたが，Lp（a）を 含め他の因子は変化を認めなかった。

考案：高齢者ではプラバスタチン投与により高脂血 症を治療することで凝固線溶系，血管内皮細胞障害 マーカーは影響をらけず血栓準備状態は改善せず，抗 凝固療法などの必要性があり，また Lp (a) は T.Chol とは異なる血栓性疾患の危険因子である可能性が示唆 された。 